\title{
Preliminary trophic network analysis of subalpine Lake Annecy (France) using an Ecopath model
}

\author{
M.Y. Janjua ${ }^{(1)}$, D. Gerdeaux ${ }^{(1)}$ \\ Received February 4, 2009 / Reçu le 4 février 2009 \\ Revised March 11, 2009 / Révisé le 11 mars 2009 \\ Accepted March 16, 2009 / Accepté le 16 mars 2009
}

\section{ABSTRACT}

Key-words: trophic model, Ecopath, Lake Annecy, fisheries
Lake Annecy is the second largest natural lake in France, with intensive commercial and recreational fisheries. However, there is limited knowledge of its trophic interaction. A preliminary Ecopath model was fitted to study the trophic interaction in the lake using the available data on most of the ecosystem compartments. Fourteen functional groups were used in the present analysis. Most of the consumers have ecotrophic efficiency from 0.3 to 0.6 . The results show that flow from detritus is as important as flow from primary producers. The overall transfer efficiency of the system is 9.6. The primary production/respiration $\left(P_{p} / R\right)$ ratio, which is 3.253, shows that Lake Annecy's ecosystem is comparatively mature. The gross efficiency of fisheries is 0.001173 . Catch trophic level and percentage of primary productivity required for catch show that fishery in Lake Annecy is stable. The values of ascendancy (31.2) and overhead (68.8) show the stability of the ecosystem. Mixed trophic analysis indicates that zoobenthos have a positive effect on most of the fish functional groups. This preliminary model can be helpful to pinpoint the gaps in the present knowledge about Lake Annecy.

\section{RÉSUMÉ}

\section{Analyse préliminaire du réseau trophique du lac d'Annecy avec le modèle Ecopath}

Le lac d'Annecy est le second plus grand lac naturel de France avec une importante pêcherie commerciale et amateur. Toutefois les connaissances sur les interactions trophiques sont limitées. Le modèle Ecopath a été ajusté pour étudier les interactions trophiques dans le lac en utilisant les données disponibles sur la plupart des compartiments de l'écosystème. Quatorze groupes fonctionnels ont été utilisés dans cette analyse. La plupart des consommateurs ont une efficience écologique qui varie de 0,3 à 0,6 . Les résultats montrent que le flux de détritus est aussi important que le flux des producteurs primaires. L'efficience globale du système est de 9,6. Le rapport production primaire/respiration $\left(P_{p} / R\right)$ de 3,253 montre que le lac d'Annecy est relativement mature. L'efficience brute de la pêcherie est de 0,001173 . Le niveau trophique des captures et le pourcentage de la production primaire requis par ces captures montrent que la pêcherie au lac d'Annecy est stable. Les valeurs de l'« ascendancy » $(31,2)$ et de l'« overhead » $(68,8)$ montrent la stabilité du système. L'analyse trophique montre que le zoobenthos a un effet positif sur la plupart des groupes fonctionnels de poissons. Ce modèle préliminaire peut être utile pour mettre le doigt sur les lacunes dans les connaissances actuelles sur le lac d'Annecy. 


\section{INTRODUCTION}

Fisheries management is moving from single species management towards an ecosystembased approach (Dame and Christian, 2006). Therefore, an understanding of trophic structure is essential for ecological studies, fishery assessment and management. The measurement of energy and material flows between the various ecosystem components provides significant insight into the fundamental structure and functioning of the system (Ulanowicz, 1986). Such complex interactions between components of ecosystems can be integrated very well using ecological models. Trophic network analysis actually evaluates the components within a food web using input/output and cycle analysis to calculate ecosystem properties. Such analysis also quantifies direct and indirect trophic effects for each component in the network and makes it possible to determine the complex dependency of one compartment on other compartments. Odum (1969) used the maturity concept to describe an ecosystem, suggesting that ecosystems without any human impact evolve in succession toward maturity. According to this concept, a mature type ecosystem is more protected and has stability and quality. Trophic network analysis can be used to quantify the health, integrity and maturity of ecosystems (Christensen, 1995; Christensen and Pauly, 1998; Ulanowicz, 2000) and also help to evaluate the magnitude of stress imposed on an ecosystem by fisheries and global changes (Mageau et al., 1998). Research efforts using trophic network analyses in ecology have produced methodological, theoretical and empirical advances and development of software packages for ecological trophic analysis. One of the important pieces of software that has been developed to perform ecological network analysis is Ecopath with Ecosim (EwE). EwE is a mass balance model which provides an excellent means of studying the behavior of an aquatic ecosystem.

Extensive ecological studies have been carried out on Lake Annecy by different organizations since the 1960s and 1970s. From 1966 to 1981 and since 1990, Lake Annecy has been monitored by "Le Syndicat Mixte du Lac d'Annecy". It includes monitoring of the physical, chemical and biological parameters of Lake Annecy with the help of the Lakes Hydrobiology Station (INRA, Thonon). A comprehensive report was published by Gerdeaux et al. (2000) on trophic functions of Lake Annecy. That report includes studies on macrobenthos, zooplankton, phytoplankton, microorganisms and diet of some important fish species. A comprehensive study was done by Gerdeaux et al. (2005) on primary production and zooplankton in Lake Annecy. Borderelle et al. (2005) studied the Lake Biotic Index based on bathymetric macroinvertebrate assemblage to assess Lake Annecy's biological quality and found it to be much higher as compared with other French subalpine lakes. Verneaux and Verneaux (2002) assessed the Lake Annecy functioning using the macrobenthic community with special reference to Chironomidae. Dubois et al. (1988) studied distribution and relative abundance of different macrophyte species. Gerdeaux et al. (2002) also studied the diet and seasonal patterns of food composition of whitefish Coregonus lavaretus in Lake Annecy in comparison with the diet of the other species of the fish community.

Little work has been reported for use of Ecopath in lake ecosystem modeling as compared with marine or coastal areas. Ecopath has been used for trophic analysis of lake ecosystems; mostly for African tropical lakes, e.g. Lake Victoria (Moreau, 1995), Lake Turkana (Kolding, 1993), Lake George (Moreau et al., 1993), Lake Chad (Palomares et al., 1993a). Lake Awassa (Fetahi and Mengistou, 2007), Lake Kivu (Villanueva et al., 2008) and Lake Ayamé (Traore et al., 2008), and a few Chinese and Indian lakes including Lake Qiandaohu (Liu et al., 2007), Wyra reservoir (Panikkar and Khan, 2008) and Lake Taihu (Li et al., 2009), and for a few temperate lakes including Lake Ontario (Halfon and Schito, 1993) and Lake Aydat in France (Reyes-Marchant et al., 1993). A few studies have been reported on French rivers and coastal areas including Garonne River (Palomares et al., 1993c), Étang de Thau Lagoon (Palomares et al., 1993b), Bay of Biscay (Ainsworth et al., 2001), Seine Estuary (Rybarczyk and Elkaïm, 2003) and Bay of Mont Saint-Michel (Arbach Leloup et al., 2008).

The present study is an attempt for the first time to make a steady-state model of trophic interactions of an oligotrophic subalpine lake in France which is very important for both 
commercial and recreational fisheries. The rationale behind this study is to quantify the trophic web structure of Lake Annecy, to evaluate the role of fisheries and to identify the data gaps. The present study can also help to have a look at the properties and status of other oligotrophic lake ecosystems and be used for comparison with other eutrophic and tropical lakes.

\section{MATERIAL AND METHODS}

\section{$>$ THE SITE}

Lake Annecy is an oligotrophic lake situated in the French department of Haute-Savoie in the Rhône-Alpes region (45 $50^{\prime} \mathrm{N}, 6^{\circ} 40^{\prime} \mathrm{E}$ ). It is the second biggest natural lake in France, about $14.6 \mathrm{~km}$ long and between $0.8 \mathrm{~km}$ and $3.2 \mathrm{~km}$ wide, with a total surface area of $2740 \mathrm{ha}$. At an altitude of $447 \mathrm{~m}$ above sea level, the maximum depth of the lake is $65 \mathrm{~m}$ and the mean depth is $41.5 \mathrm{~m}$. The mean annual temperature of the lake water is about $10^{\circ} \mathrm{C}$ and the area has an average of about 2036 sunshine hours per year. Fishing is a very important practice in Lake Annecy. At the beginning of the 19th century the fish community was very poor as compared with other lakes. From the end of the 19th century, new fish species including whitefish and Arctic char were introduced (Le Roux, 1911). Since the beginning of the 20th century, with the introduction of new species it has evolved into a more typical composition of subalpine lakes, with the disappearance of some native species and development of whitefish and Arctic char. Marked changes during the last two decades have been described in both zooplankton and fish communities in the Lake Annecy (Gerdeaux et al., 2002). Now, the fish fauna of Lake Annecy consists of about fourteen species. Significant among these are common Whitefish (Coregonus lavaretus), Arctic char (Salvelinus alpinus), Trout (Salmo trutta lacustris), Pike (Esox lucius), Perch (Perca fluviatilis), Burbot (Lota lota), Tench (Tinca tinca), Roach (Rutilus rutilus) and common Carp (Cyprinus carpio). Lake Annecy has a high density of macrobenthos compared with other French lakes. Important groups are oligochetes (44\% of individual density), mollusks (Pisidium) and chironomids, especially Procladius, Cladotanytarsus and Tanytarsus $(28 \%$ of individual density) (Verneaux and Verneaux, 2002). Important zooplankton taxa are Cladocera (Daphnia sp., Diaphanosoma brachyurum, Bosmina longirostris and Mesocyclops leuckarti) and Copepods (Cyclops prealpinus). Phytoplankton are dominated by Diatoms (Fragilaria crotonensis) and Chrysophyta (Dinobryon sociale). Submerged vegetation is mostly dominated by Charophyceae. The main stakeholders of Lake Annecy fisheries are two types of fishermen, recreational (anglers) and commercial. At present, there are more than one thousand recreational fishermen and four commercial fishermen. Commercial fishermen use bottom and pelagic gillnets while anglers catch fish mostly with leadline (Gerdeaux and Janjua, 2009).

\section{$>$ ECOPATH}

Ecopath with Ecosim (EwE 6.0) allows rapid construction, verification and analysis of mass balance models of ecosystems with a focus on use for proper and sustainable fishery management (Christensen and Walters, 2004). EwE has been under continuous development for more than two decades. In Ecopath, a system is partitioned into functional groups having a common physical habitat, similar diet and life history characteristics or ecological similarities. A group in an Ecopath model may be a group of related species, a single species, or a single size/age group of a given species. For each functional group, values of the biomass $(B)$, production/biomass ratio $(P / B)$, consumption/biomass ratio $(Q / B)$, diet composition (DC) and ecotrophic efficiency (EE) need to be determined. EwE can inform the user whether the model is mass-balanced. The Ecopath model assumes mass balance when production of any given prey is equal to or more than the biomass consumed by predators plus the biomass caught (fishing) plus any exports from the system. A detailed description of Ecopath and its various parameters can be found in Christensen et al. (2005). 


\section{> FUNCTIONAL GROUPS}

The different fish functional groups used for Ecopath modeling of Lake Annecy include Common whitefish (Coregonus lavaretus), Arctic char (Salvelinus alpinus), Trout (Salmo trutta lacustris), Pike (Esox lucius), Perch (Perca fluviatilis), Burbot (Lota lota), Tench (Tinca tinca) and Roach (Rutilus rutilus). All other minor species were grouped as Cyprinids. Two significant species in fish catch, whitefish and Arctic char, were divided into bi-stanza groups on the basis of legal and below legal size in fisheries in order to study the impact of commercial and recreational fish catch on various functional groups. Perch is another important fish species in Lake Annecy and was divided into Young of the Year (YoY) and adult stanzas because of its importance in the prey-predator relationship and fish catch. Other important groups used for modeling include zoobenthos, zooplankton, phytoplankton, macrophytes and detritus.

\section{> FISHERIES DATA}

\section{Biomass}

Data obtained from commercial and recreational exploitation of fisheries in Lake Annecy from 2000 to 2006 (Gerdeaux and Crepeau, 2006) was used to estimate comparative biomass of important fish species. Fish biomass was also adjusted according to the preypredator relationship and ecotrophic efficiencies using the automatic mass balance option in EwE software. Biomass and Q/B of YoY perch, Arctic char $(<26 \mathrm{~cm} \mathrm{TL})$ and whitefish $(<38 \mathrm{~cm} \mathrm{TL})$ were calculated using the group stanzas option in EwE by entering the biomass, Q/B of higher stanzas, $\mathrm{K}$ value in the Von Bertalanffy Growth Function (VBGF) and mortality rate for all stanzas (Christensen and Walters, 2004).

\section{Growth}

Data obtained from commercial and recreational exploitation of fisheries in Lake Annecy was used to estimate various fish growth parameters, e.g. $L_{\infty}$ (asymptotic length), $L_{\max }$, (maximum length) and $\mathrm{K}$ (curvature parameter of the VBGF) using different empirical relationships suggested by Froese and Binohlan (2000).

\section{Production/biomass ratio (P/B)}

Production/biomass ratios are difficult to estimate directly and were taken as equal to total mortality (Z) (Pauly et al., 2000). Total mortality (Z) of exploited fish species was determined by summing the value of fishing mortality $(F)$ and natural mortality $(M)$ as $Z=F+M$. $F$ was determined by using commercial and recreational fish catch data and estimated biomass.

Natural mortality (M) was estimated using Pauly's empirical relationship (Pauly, 1980)

$$
\mathrm{M}=\mathrm{K}^{0.65} \times \mathrm{L}_{\infty}^{-0.279} \times \mathrm{T}_{\mathrm{C}}^{0.463}
$$

where $M$ is natural mortality (year ${ }^{-1}$ ); $L_{\infty}$ is the asymptotic length (total length, $c m$ ) and $T_{C}$ is the mean water temperature in ${ }^{\circ} \mathrm{C}$. For unexploited fish species $M$ was directly taken as $\mathrm{P} / \mathrm{B}$.

\section{Consumption/biomass ratio (Q/B)}

Q/B was estimated for each consumer functional group using the relationship suggested by Palomares and Pauly (1998):

$$
\log (Q / B)=7.964-0.204 \log W_{i n f}-1.965 T+0.083 A+0.532 h+0.398 d
$$

where $\mathrm{W}_{\text {inf }}$ is the asymptotic weight (g); $\mathrm{T}$ is an expression for the mean annual temperature of the water body, expressed using $\mathrm{T}=1000 / \mathrm{K}\left(\mathrm{K}={ }^{\circ} \mathrm{C}+273.15\right)$; $\mathrm{A}$ is the aspect ratio 
$\left(A=h_{c}{ }^{2} / s\right)$ of the caudal fin of fish, given the height of the caudal fin $\left(h_{c}\right)$ and surface area of the caudal fin (s); $h$ is a dummy variable expressing food type $(1$ for herbivores and 0 for detritivores and carnivores), and $d$ is also a dummy variable expressing food type (1 for detritivores and 0 for herbivores and carnivores).

\section{Fish catch}

In Lake Annecy, important species in fisheries are mainly salmonids, Arctic char, whitefish and trout, which represent more than $80 \%$ of the yield. Pike and perch make up $10 \%$ of the yield. Burbot and some cyprinids, roach and common carp make up the remaining $10 \%$ of total catch. Two important types of fisheries, commercial and recreational, were treated as separate fleets in the Ecopath model. The mean of commercial and recreational fish catch data was used to estimate fish catch in $\mathrm{t} \cdot \mathrm{km}^{-2} \cdot \mathrm{year}^{-1}$.

\section{>ZOOBENTHOS}

Some studies on zoobenthos of Lake Annecy have been done in the past (Gerdeaux et al., 2000; Verneaux and Verneaux, 2002) but were mostly confined to species richness, relative abundance and density. No published data was found on actual zoobenthos biomass in Lake Annecy. Data from the above-mentioned studies was utilized to determine dominant species and their production/ biomass (P/B) ratio was estimated at 5.2 per year as an average for dominant species (Jorgensen, 1979). Gross food conversion efficiency (P/Q) was assumed to be 0.20 (Christensen et al., 2005; Fetahi and Mengistou, 2007) and ecotrophic efficiency was taken as 0.95 after Reyes-Marchant et al. (1993) and Fetahi and Mengistou (2007) to calculate the minimum zoobenthos biomass and consumption biomass ratio (Q/B).

\section{$>$ ZOOPLANKTON}

Mean zooplankton biovolume, averaged as $65 \mathrm{~mL} \cdot \mathrm{m}^{-2}$ from 1996-2005 (Gerdeaux et al., 2005), was used to calculate biomass after Balvay (1987). The average of the $P / B$ ratio was estimated at 19 year $^{-1}$ (Jorgensen, 1979). Gross food conversion efficiency (P/Q) was assumed to be 0.25 to calculate the Q/B ratio (Reyes-Marchant et al., 1993; Fetahi and Mengistou, 2007).

\section{> PHYTOPLANKTON AND PRIMARY PRODUCTION}

Annual mean hourly primary production $\left(3.24 \mu \mathrm{C} \cdot \mathrm{L}^{-1} \cdot \mathrm{h}^{-1}\right)$ (Gerdeaux et al., 2000) was used to calculate the total phytoplankton biomass production rate $\left(979.60 \mathrm{t} \cdot \mathrm{km}^{-2} \cdot \mathrm{year}^{-1}\right)$. Annual phytoplankton production $\mathrm{km}^{-2}$ was divided by the annual mean phytoplankton biomass (11.25 t.km ${ }^{-2}$.year ${ }^{-1}$, Gerdeaux et al., 2000) to calculate the P/B ratio.

\section{$>$ MACROPHYTES}

Macrophytes in Lake Annecy are dominated by Charophycea. Biomass for macrophytes was calculated, assuming their primary production per unit area to be equal to phytoplankton (Reyes-Marchant et al., 1993) for $13.7 \%$ of the total surface area of the lake (Dubois et al., 1988) and the P/B ratio to be 10 (Reyes-Marchant et al., 1993).

\section{$>$ DETRITUS}

Detritus biomass (D) was calculated with the Ecoempire function of EwE using the empirical relationship suggested by Christensen et al. (2005):

$$
\log \mathrm{D}=0.954 \log \mathrm{PP}+0.863 \log \mathrm{E}-2.41
$$


where $\mathrm{D}=$ detrital biomass $\left(\mathrm{g} \cdot \mathrm{m}^{-2}\right)$; $\mathrm{PP}=$ primary production (in $\left.\mathrm{gC} \cdot \mathrm{m}^{-2} \cdot \mathrm{year}^{-1}\right)(97.96)$, and $E=$ euphotic depth in meters (14.85).

\section{> DIET INFORMATION}

For whitefish, Arctic char and perch, diet matrices were estimated using published literature and reports on Lake Annecy (Gerdeaux et al., 2002) (Table II). For functional groups for which there was no data available specifically for Lake Annecy, diet composition was estimated using published data from similar conditions (Bailey, 1972; Treasurer et al., 1992; Halfon and Schito, 1993; Jamet, 1994; Michel and Oberdorff, 1995). Due to unavailability of specific literature, the diet of pike was estimated, keeping in mind the fish composition in Lake Annecy and literature from other areas.

\section{$>$ MODEL BALANCING}

If the Ecotrophic Efficiency (EE) of any group is more than 1, it shows that the model is not balanced. A mass balance facility is available in the Ecopath model to balance the model by modifying biomass, the production/biomass ratio and diet. The mass balance routine was used to calibrate model parameters and to obtain all EE less than 1.0 and gross efficiency $(P / Q)$ from 0.1 to 0.3 . The data for this model was assigned an Ecopath Pedigree Index of 0.422 .

\section{> MODEL ANALYSIS}

After balancing the model, ecological analysis integrated in EwE was used to examine different indicators which describe trophic flows and transfer efficiencies. Some of these results were related to the maturity of the ecosystem and some provide information about fisheries stability. Odum (1971) proposed that the system primary production to respiration ratio $\left(\mathrm{P}_{\mathrm{p}} / \mathrm{R}\right)$ would approach unity in mature ecosystems, while the primary production to total biomass ratio $\left(P_{p} / B\right)$ and total system biomass to the total system throughput ratio (B/TST) values tend to be low in mature ecosystems (Christensen, 1995). Ascendancy is also a key index which characterizes the maturity of an ecosystem (Ulanowicz, 1986). Relative values of ascendancy and overhead can be used to evaluate ecosystem health (Christensen, 1998; Brando et al., 2004). These indices were used to analyze the properties of the lake's ecosystem. Another routine available in Ecopath is one which aggregates the entire ecosystem into trophic levels and efficiencies of transfer within these trophic levels (Christensen et al., 2005). Mixed Trophic Impact Analysis (MTI), developed by Ulanowicz and Puccia (1990), has been implemented in the Ecopath model and was also used to study the impact of direct and indirect interactions.

\section{RESULTS}

Various basic input parameters and the resulting estimates of trophic levels (TL), EE and $P / Q$ are presented in Table I. Diet compositions of various functional groups are given in Table II. Most of the fish functional groups are represented at species level, which increases the precision of the estimates, and this data appears to represent Lake Annecy efficiently. EE values usually range from zero in top predators to 1 . The EE of most of the commercial fish species in Lake Annecy was less than 0.5. The low value of phytoplankton and macrophytes' EE shows that only a small proportion of total phytoplankton production is utilized and the rest goes to detritus. EE of zooplankton and detritus was also low. Gross efficiency was lower for cyprinids and roach because of the low quality of their preferred prey, including zooplankton and macrophytes.

One of the characteristics of EwE is a flow diagram showing biomass, energy flow and consumption (Figure 1). Ecopath can calculate the fractional trophic level for each group, 
Table I

Basic parameters (result of mass balance adjustment) used for analysis of Lake Annecy. Derived estimates by EwE are in bold text.

Tableau I

Paramètres de base (résultant de l'ajustement du bilan de masse) utilisés dans l'analyse du lac d'Annecy. Les valeurs estimées par EwE sont en gras.

\begin{tabular}{|l|c|c|c|c|c|c|c|}
\hline No. & Group & $\begin{array}{c}\text { Trophic } \\
\text { level }\end{array}$ & $\begin{array}{c}\text { Biomass } \\
\left(\mathrm{t} \cdot \mathrm{km}^{-2}\right)\end{array}$ & $\begin{array}{c}\mathrm{P} / \mathrm{B} \\
\left(\mathrm{year}^{-1}\right)\end{array}$ & $\begin{array}{c}\mathrm{Q} / \mathrm{B} \\
\left(\mathrm{year}^{-1}\right)\end{array}$ & $\mathrm{EE}$ & $\mathrm{P} / \mathrm{Q}$ \\
\hline $\mathbf{1}$ & Pike & $\mathbf{4 . 0}$ & 0.456 & 0.430 & 1.851 & $\mathbf{0 . 5 1 6}$ & $\mathbf{0 . 2 3 2}$ \\
\hline $\mathbf{2}$ & Burbot & $\mathbf{3 . 6}$ & 0.115 & 0.437 & 3.134 & $\mathbf{0 . 8 3 3}$ & $\mathbf{0 . 1 4 0}$ \\
\hline $\mathbf{3}$ & Arctic char $>26$ & $\mathbf{3 . 3}$ & 1.045 & 0.474 & 3.089 & $\mathbf{0 . 4 6 5}$ & $\mathbf{0 . 1 5 3}$ \\
\hline $\mathbf{4}$ & Arctic char $<26$ & $\mathbf{3 . 2}$ & $\mathbf{0 . 2 5 3}$ & 0.770 & $\mathbf{6 . 7 2 5}$ & $\mathbf{0 . 3 5 3}$ & $\mathbf{0 . 1 1 5}$ \\
\hline $\mathbf{5}$ & Trout & $\mathbf{3 . 4}$ & 0.350 & 0.356 & 2.277 & $\mathbf{0 . 3 8 1}$ & $\mathbf{0 . 1 5 6}$ \\
\hline $\mathbf{6}$ & Tench & $\mathbf{3 . 2}$ & 0.250 & 0.651 & 2.700 & $\mathbf{0 . 3 5 0}$ & $\mathbf{0 . 2 4 1}$ \\
\hline $\mathbf{7}$ & Perch adult & $\mathbf{3 . 2}$ & 2.155 & 0.543 & 3.594 & $\mathbf{0 . 1 3 9}$ & $\mathbf{0 . 1 5 1}$ \\
\hline $\mathbf{8}$ & Perch YoY & $\mathbf{3 . 2}$ & $\mathbf{0 . 1 2 3}$ & 4.500 & 15.464 & $\mathbf{0 . 8 4 0}$ & $\mathbf{0 . 2 9 1}$ \\
\hline $\mathbf{9}$ & Whitefish $>38$ & $\mathbf{3 . 1}$ & 4.036 & 0.516 & 2.576 & $\mathbf{0 . 4 2 3}$ & $\mathbf{0 . 2 0 0}$ \\
\hline $\mathbf{1 0}$ & Whitefish $<38$ & $\mathbf{3 . 0}$ & $\mathbf{1 . 1 4 6}$ & 0.384 & $\mathbf{4 . 8 1 2}$ & $\mathbf{0 . 7 6 3}$ & $\mathbf{0 . 0 8 0}$ \\
\hline $\mathbf{1 1}$ & Cyprinids & $\mathbf{2 . 7}$ & 0.485 & 0.539 & 12.383 & $\mathbf{0 . 8 2 8}$ & $\mathbf{0 . 0 4 3}$ \\
\hline $\mathbf{1 2}$ & Roach & $\mathbf{2 . 5}$ & 2.492 & 0.435 & 12.970 & $\mathbf{0 . 8 0 0}$ & $\mathbf{0 . 0 3 4}$ \\
\hline $\mathbf{1 3}$ & Zoobenthos & $\mathbf{2 . 3}$ & $\mathbf{4 . 8 8 0}$ & 6.072 & $\mathbf{2 4 . 8 7 0}$ & 0.950 & 0.244 \\
\hline $\mathbf{1 4}$ & Zooplankton & $\mathbf{2 . 0}$ & 8.605 & 18.603 & 69.145 & $\mathbf{0 . 3 0 9}$ & 0.269 \\
\hline $\mathbf{1 5}$ & Phytoplankton & $\mathbf{1 . 0}$ & 11.038 & 82.862 & - & $\mathbf{0 . 3 6 5}$ & - \\
\hline $\mathbf{1 6}$ & Macrophytes & $\mathbf{1 . 0}$ & 12.634 & 8.351 & - & $\mathbf{0 . 3 3 3}$ & - \\
\hline $\mathbf{1 7}$ & Detritus & $\mathbf{1 . 0}$ & 3.200 & - & - & $\mathbf{0 . 3 4 8}$ & - \\
\hline
\end{tabular}

and the highest realized TL obtained was 4.05 for Pike. The system statistics of Lake Annecy's ecosystem are given in Table III. Primary production in the lake reached up to $1216 \mathrm{t} \cdot \mathrm{km}^{-2}$.year ${ }^{-1}$. A total of 973 tonnes of detritus was recycled into the system per square kilometer per year. The flows in Lake Annecy can be distributed on discrete trophic levels by Ecopath (Table IV). Trophic structure analysis shows that most of the biomass and flows were confined to trophic levels I and II. Trophic flow from TL I to TL II was $707.53 \mathrm{t} \cdot \mathrm{km}^{-2} \cdot \mathrm{year}^{-1}$, which is only $34 \%$ of the total biomass at TL I. The trophic transfer efficiency was higher at TL III and lowest at TL IV. The average trophic transfer level of the Lake Annecy system was $9.0 \%$. In Lake Annecy, flow into detritus dominated the total system throughput (TST), accounting for $57.30 \%$, followed by consumption at $30.29 \%$. Flow to detritus was mainly from zooplankton, phytoplankton and macrophytes. The total primary production/total biomass ratio of the system was found to be 20.41 (Table III). The value of B/TST was 0.018 and the relative value of ascendancy was 31.2, which is low with relatively high overhead (Table IV).

Most of the fish production was confined to TL III, and to some extent, to TL IV. The mean trophic level of catch was 3.17, as it exploits a high proportion of coregonids. More than $80 \%$ of the fish catch was confined to trophic level 3 (Table VI). The total primary production requirement for sustainable catch was estimated at $15.03 \%$, with the highest requirement for pike at $6.29 \%$ followed by whitefish at $4.17 \%$. 


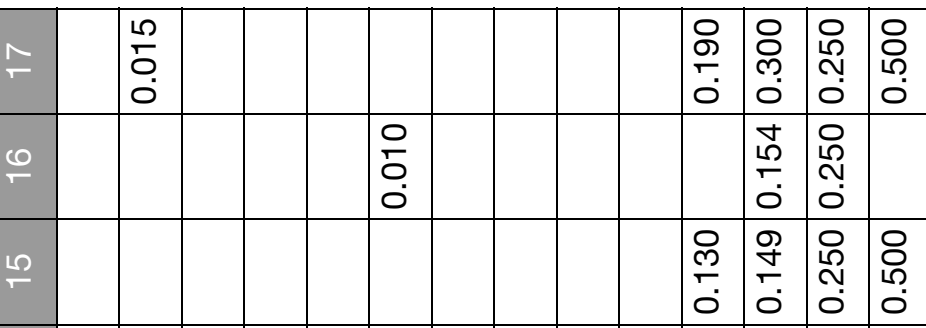

율

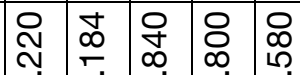




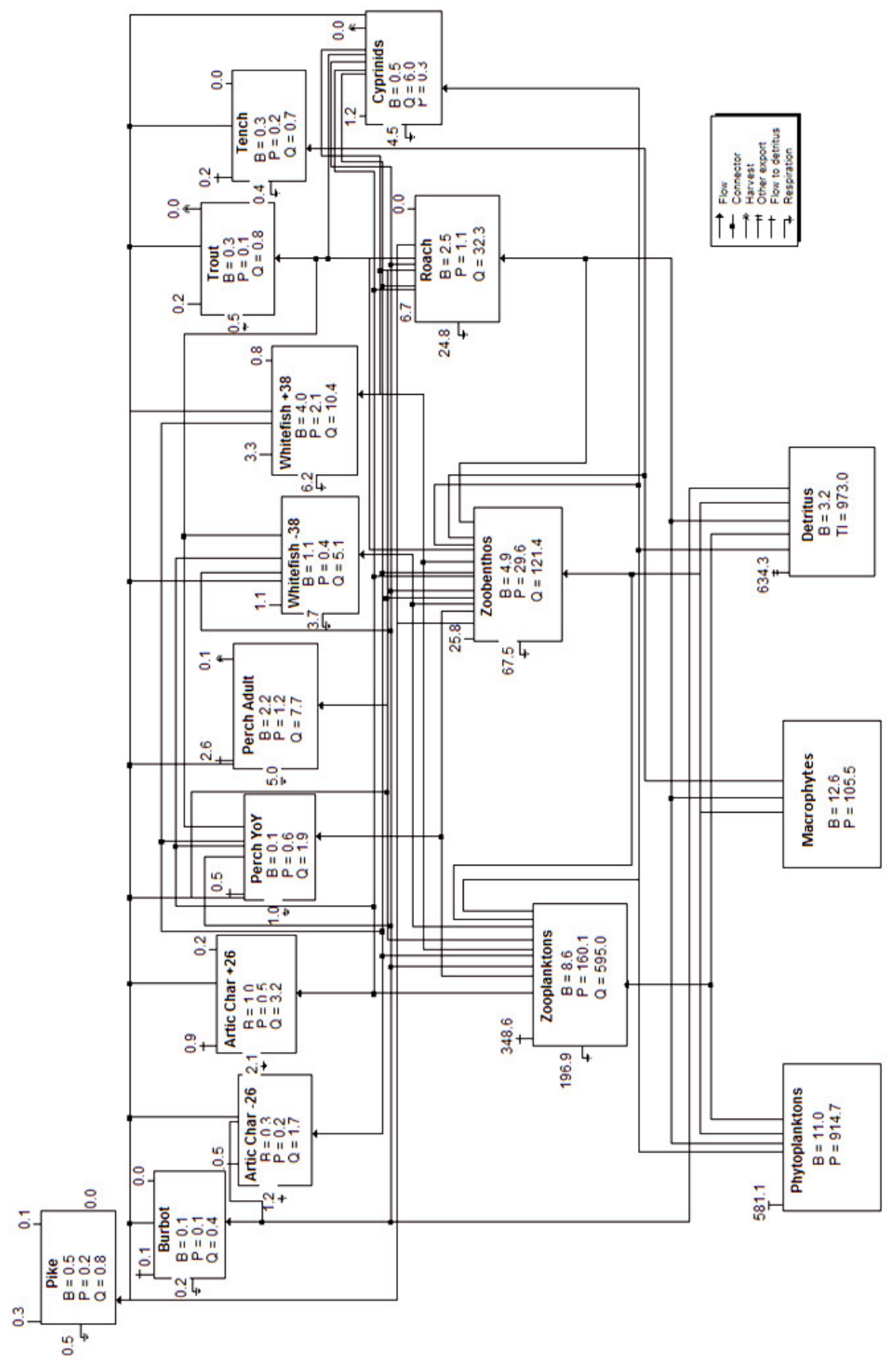

เองәา วบชอมเ

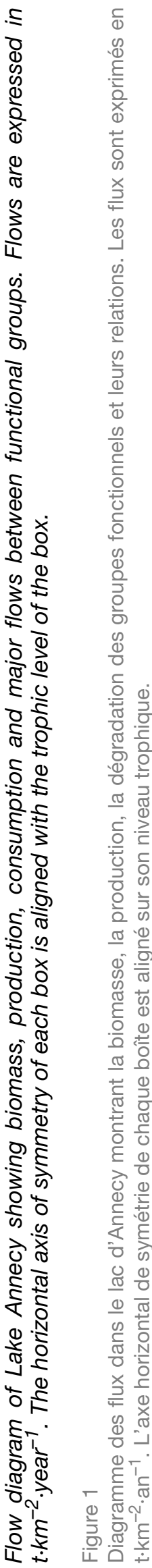


Table III

System statistics of Lake Annecy. Various efficiencies and indices are dimensionless.

Tableau III

Données sur le lac d'Annecy. Les diverses valeurs d'efficience et les indices sont sans dimension.

\begin{tabular}{|l|c|c|}
\hline Parameter & Value & Units \\
\hline Sum of all consumption & 787.438 & $\mathrm{t} \cdot \mathrm{km}^{-2} \cdot \mathrm{year}^{-1}$ \\
\hline Sum of all exports & 635.535 & $\mathrm{t} \cdot \mathrm{km}^{-1}$ \\
\hline Sum of all respiratory flows & 314.462 & $\mathrm{t} \cdot \mathrm{km}^{-1}$ \\
\hline Sum of all flows into detritus & 973.015 & $\mathrm{t} \cdot \mathrm{km}^{-1}$ \\
\hline Total system throughput & 2710 & $\mathrm{t} \cdot \mathrm{km}^{-1}$ \\
\hline Sum of all production & 1216 & $\mathrm{t} \cdot \mathrm{km}^{-1}$ \\
\hline Mean trophic level of the catch & 3.17 & \\
\hline Gross efficiency (catch/net p.p.) & 0.001172 & $\mathrm{t} \cdot \mathrm{km}^{-2} \cdot \mathrm{year}^{-1}$ \\
\hline Calculated total net primary production & 1020.159 & \\
\hline Total primary production/total respiration & 3.244 & $\mathrm{t} \cdot \mathrm{km}^{-2} \cdot \mathrm{year}^{-1}$ \\
\hline Net system production & 705.697 & \\
\hline Total primary production/total biomass & 20.412 & \\
\hline Total biomass/total throughput & 0.018 & $\mathrm{t} \cdot \mathrm{km}^{-2}$ \\
\hline Total biomass (excluding detritus) & 49.979 & $\mathrm{t} \cdot \mathrm{km}^{-2} \cdot \mathrm{year}^{-1}$ \\
\hline Total catches & 1.196 & \\
\hline Connectance Index & 0.258 & \\
\hline System Omnivory Index & 0.107 & \\
\hline
\end{tabular}

The MTI of various functional groups are given in Figure 2. Pike has a negative MTI on all other fish species except whitefish and roach, which maintained a good population despite the catching pressure. The MTI also shows the positive impact of zoobenthos on most of the fishes, except whitefish. Phytoplankton, zooplankton and detritus also have a positive impact on most of the consumer fish groups. Both commercial and amateur fisheries show a mixed type of impact. Commercial fisheries show a negative impact on most of the commercially and recreationally important fish groups, except Arctic char for which it is a little positive. Recreational fisheries' impact is negative on whitefish, Arctic char and pike. Both types of fisheries show a positive impact on carps, which are not commercially important in Lake Annecy.

\section{DISCUSSION}

The Ecotrophic Efficiencies (EE) of most of the functional groups were less than 0.5 . This is in accordance with Dickie (1972), who stated that it is quite unlikely to have EE efficiency greater than 0.5 because it may be unstable. The EE of pike, above 0.51 , was quite high considering its status as top predator, but it is possible because of its high fishing mortality. Minimum EE was found for adult perch (0.139), which shows less fishing and predation pressure on adults, being divided into YoY and adult stanzas. YoY perch showed the highest EE because of high predation pressure from pike, Arctic char and trout and also because 


\section{Table IV}

Trophic aggregation of flows in Lake Annecy ecosystem showing how flows $\left(t \cdot \mathrm{km}^{-2} \cdot y e a r^{-1}\right)$ are distributed by trophic levels.

\section{Tableau IV}

Agrégation des flux trophiques $\left(\mathrm{t} \cdot \mathrm{km}^{-2} \cdot \mathrm{an}^{-1}\right)$ dans l'écosystème du lac d'Annecy montrant comment ils sont distribués par niveau trophique.

\begin{tabular}{|l|c|c|c|c|c|c|}
\hline & Group & I & II & III & IV & V \\
\hline $\mathbf{1}$ & Pike & - & - & 0.139 & 0.562 & 0.125 \\
\hline $\mathbf{2}$ & Burbot & - & 0.005 & 0.171 & 0.154 & 0.025 \\
\hline $\mathbf{3}$ & Arctic char $>26$ & - & - & 1.346 & 0.346 & 0.009 \\
\hline $\mathbf{4}$ & Arctic char $<26$ & - & - & 2.336 & 0.841 & 0.052 \\
\hline $\mathbf{5}$ & Trout & - & - & 0.531 & 0.264 & 0.016 \\
\hline $\mathbf{6}$ & Tench & - & 0.007 & 0.499 & 0.166 & - \\
\hline $\mathbf{7}$ & Perch adult & - & - & 1.530 & 0.371 & - \\
\hline $\mathbf{8}$ & Perch YoY & - & - & 6.097 & 1.627 & 0.023 \\
\hline $\mathbf{9}$ & Whitefish > 38 & - & - & 4.904 & 0.204 & - \\
\hline $\mathbf{1 0}$ & Whitefish <38 & - & - & 9.810 & 0.556 & 0.032 \\
\hline $\mathbf{1 1}$ & Cyprinids & - & 1.915 & 3.919 & 0.150 & - \\
\hline $\mathbf{1 2}$ & Roach & - & 19.539 & 9.648 & 3.216 & - \\
\hline $\mathbf{1 3}$ & Zoobenthos & - & 91.091 & 30.364 & - & - \\
\hline $\mathbf{1 4}$ & Zooplankton & - & 594.976 & - & - & - \\
\hline $\mathbf{1 5}$ & Phytoplankton & 914.540 & - & - & - & - \\
\hline $\mathbf{1 6}$ & Macrophytes & 35.327 & - & - & - & - \\
\hline $\mathbf{1 7}$ & Detritus & 973.015 & - & - & - & - \\
\hline & Total & 1922.882 & 707.532 & 71.294 & 8.457 & 0.282 \\
\hline
\end{tabular}

\section{Table $V$}

Percentage of ascendancy, overhead and capacity in import, internal flow, export and respiration.

Tableau $\mathrm{V}$

Pourcentages d'« ascendency », « overhead », flux d'import-export et respiration.

\begin{tabular}{|l|c|c|c|}
\hline Source & Ascendancy (\%) & Overhead (\%) & Capacity (\%) \\
\hline Internal flow & 14.1 & 53.6 & 67.8 \\
\hline Export & 10.5 & 4.6 & 15.2 \\
\hline Respiration & 6.5 & 10.5 & 17.1 \\
\hline Total & 31.2 & 68.8 & 100 \\
\hline
\end{tabular}

of some cannibalism. The high EE of cyprinids even in the absence of much fishing pressure is because of low biomass and predation mortality. EE of all commercially important fish groups were less than 0.5 , showing sustainable fisheries. The comparatively low EE for zooplankton are quite obvious because it mostly comprises the food of whitefish only, 


\section{Table VI}

Trophic structure of Lake Annecy as summarized by Ecopath.

Tableau VI

Structure trophique du lac d'Annecy représentée par Ecopath.

\begin{tabular}{|l|c|c|c|c|c|}
\hline $\begin{array}{l}\text { Trophic Level } \\
(\mathrm{TL})\end{array}$ & $\begin{array}{c}\text { Catch } \\
\left(\mathrm{t} \cdot \mathrm{km}^{-2} \cdot \text { year }^{-1}\right)\end{array}$ & $\%$ per TL & $\begin{array}{c}\text { Biomass } \\
\left(\mathrm{t} \cdot \mathrm{km}^{-2}\right)\end{array}$ & $\%$ per TL & $\begin{array}{c}\text { Transfer } \\
\text { efficiency (\%) }\end{array}$ \\
\hline V & 0.019 & 1.59 & 0.121 & 0.59 & 8.2 \\
\hline IV & 0.178 & 14.90 & 1.852 & 8.45 & 5.5 \\
\hline III & 0.981 & 82.09 & 10.405 & 39.50 & 13.2 \\
\hline II & 0.017 & 1.42 & 13.927 & 51.46 & 10.1 \\
\hline
\end{tabular}

which does not feed on copepods, an important component of zooplankton biomass. The comparatively low EE of phytoplankton shows that only a small portion of phytoplankton production was used for grazing and the rest goes to detritus. There could be an increase in phytoplankton efficiency considering bacteria as a functional group, which is not possible at present because of data gaps.

Odum (1969) described on the basis of 24 attributes of ecosystem maturity that without any human perturbation ecosystems tend to develop towards maturity. According to Christensen and Pauly (1992), the system of linear equations in Ecopath defines many of Odum's attributes. The system primary production/respiration ratio $\left(P_{p} / R\right)$ describes the maturity of an ecosystem (Odum, 1969). During the early stages of ecosystem development, $P_{p} / R$ is higher than one but with maturity it decreases and approaches 1 when energy fixed is balanced by maintenance. In systems suffering from pollution or exploitation, this ratio is expected to be less than 1. The $P_{p} / R$ ratio of Lake Annecy was 3.24, which is less than cold water Lake Ontario in Canada (Halfon and Schito, 1993), Lake Aydat (Reyes-Marchant et al., 1993) in France, Lake Taihu (Li et al., 2009) and Lake Qiandaohu (Liu et al., 2007) in China and tropical Lake Awassa (Fetahi and Mengistou, 2007). However, this ratio is higher than 1 and most likely because only a limited quantity of organic matter is imported by the rivers and production of all the groups is not being utilized and therefore is lost in the sediments, as described by Villanueva et al. (2008) for Lake Kivu.

The Primary production/biomass ratio ( $\mathrm{Pp} / \mathrm{B})$ was 20.41, which is also rather less than some cold water lakes: 165.33 for Lake Ontario (Halfon and Schito, 1993), 67.43 for Lake Aydat (Reyes-Marchant et al., 1993), 73.95 in Lake Qiandaohu (Liu et al., 2007), 52.35 in Lake Kivu (Villanueva et al., 2008) and 28.67 in Lake Awassa (Fetahi and Mengistou, 2007), showing that the system is relatively in a mature state. The total system biomass that is supported by the available energy flow in a system can be expected to increase to a maximum for the most mature stages of a system (Odum, 1971). The ratio of total system biomass to the total system throughput (B/TST) is directly proportional to system maturity, where the estimated value tends to be low during the ecosystem development phase and increases as a function of maturity (Christensen, 1995). The value of B/TST in Lake Annecy (0.018) is high comparable with some other lake ecosystems, e.g. 0.007 in Lake Aydat (Reyes-Marchant et al., 1993), 0.003 in Lake Ontario (Halfon and Schito, 1993), 0.008 in Lake Kivu (Villanueva et al., 2008), 0.004 in Lake Qiandaohu (Liu et al., 2007) and 0.016 in Lake Awassa (Fetahi and Mengistou, 2007), showing the relative maturity of the ecosystem. From the present analysis, we can determine the relative maturity of the ecosystem; however, it is not possible to determine the direction of development.

The trophic transfer efficiency was highest in Lake Annecy at TL III due to the high EE of zoobenthos, roach and cyprinids. It was lowest at TL IV because of the comparatively low EE of perch and whitefish. Low transfer efficiencies at higher trophic levels have been observed in other aquatic ecosystems (Stachowicz et al., 2002; Villanueva et al., 2008). The average 
IMPACTED GROUP

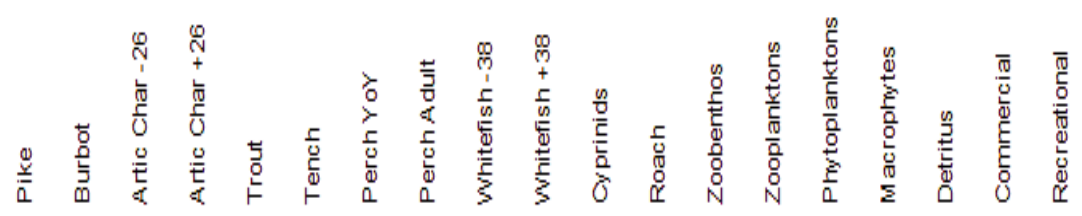

Pike

Burbot

Artic Char -26

Artic Char +26

Trout

Tench

Perch YoY

Perch Adult

Whitefish -38

Whitefish +38

Cyprinids

Roach

Zoobenthos

Zooplanktons

Phytoplanktons

Macrophytes

Detritus

Commercial

Recreational
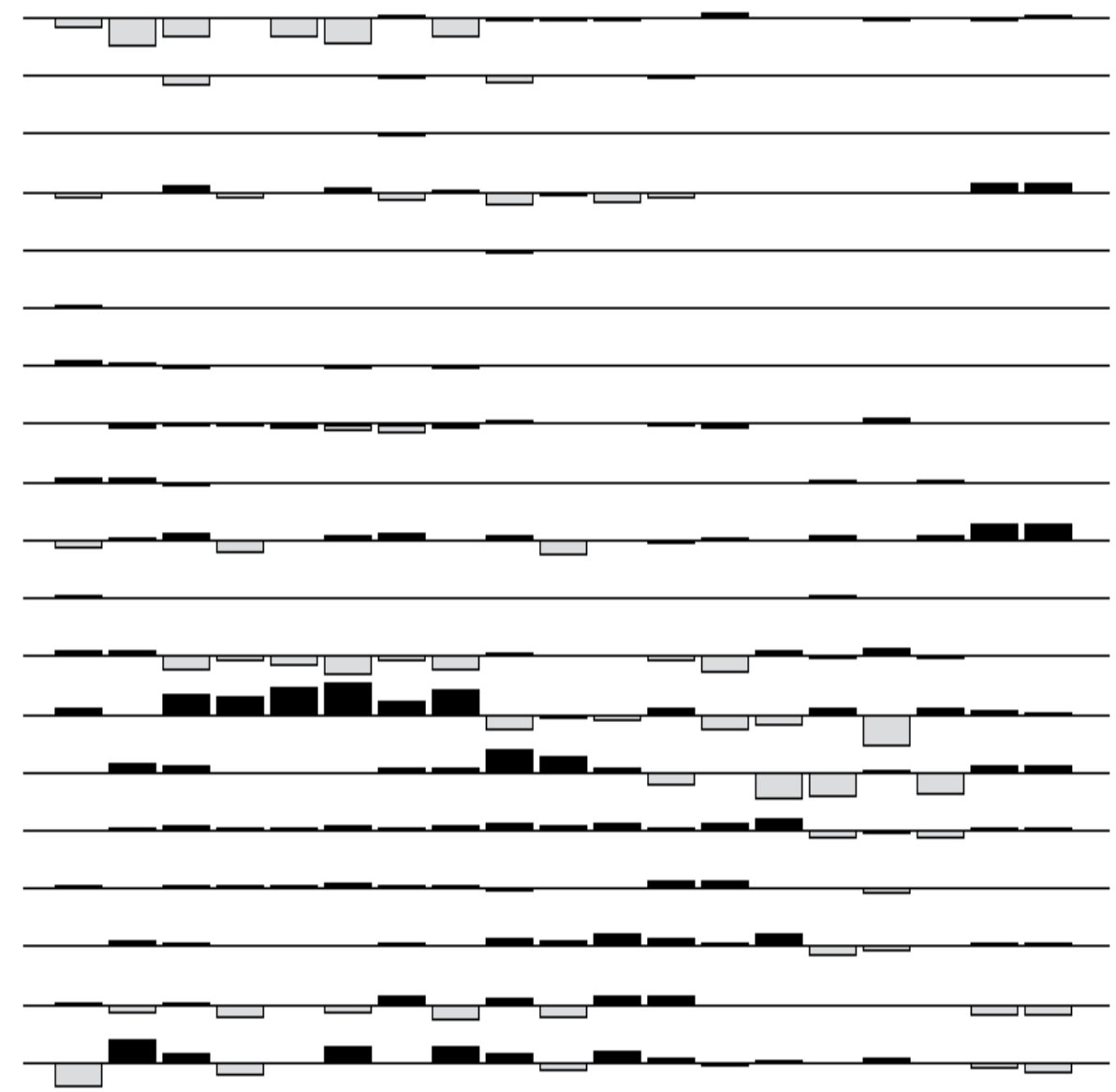

\section{Figure 2}

Mixed trophic impacts in Lake Annecy's food web. The bars quantify the direct and indirect impacts that the groups on the left have on those on the top. Positive impacts are shown above the baseline and negative impacts are below the baseline. The impacts are relative and comparable between groups.

\section{Figure 2}

Impacts trophiques dans le réseau du lac d'Annecy. Les barres quantifient les impacts directs et indirects que les groupes sur la gauche ont sur ceux du haut du tableau. Les impacts positifs sont portés au-dessus de la ligne de base, et les impacts négatifs en dessous. Les impacts sont relatifs et comparables entre groupes.

trophic transfer level of the Lake Annecy system was 9.0\%, which is a little less than the estimated unique value of 10 (Lindeman, 1942; Pauly and Christensen, 1995) and within the limit of (8-15\%) described by Christensen and Pauly (1993) and Wolff (1994). According to Lampert et al. (1997), 80-95\% of the energy is lost at each transfer in the food chain. The sinking of a large portion of phytoplankton and macrophytes into detritus is reflected in the higher total flow originating from detritus. These results show the importance of detritus 
in the Lake Annecy ecosystem. Detritus was found to be almost $50 \%$ of the total system throughput and had an important role in the lake ecosystem. According to Odum (1969), in an immature ecosystem, the food web structure is more linear with the dominance of the grazing food chain. However, in Lake Annecy the detrivorous food chain is almost equal to the grazing food chain. Domaizon et al. (2003) found that mixotrophic flagellates feeding heterotrophic bacteria represent an important link in the flux of materials through planktonic food webs in Lake Annecy. Verneaux and Verneaux (2002) also suggested a food supply other than phytoplankton for macrobenthos in Lake Annecy. Addition of a microbial loop in the model can give a clearer picture.

The growth of a system is not simply an increase in biomass, but mainly due to the number of the compartments and the amount of flow between them (Ulanowicz, 1986). Ascendancy is a measurement of system growth and development of network links. The fraction of a system's capacity not considered as ascendancy is considered as the system's overhead, which is the energy in reserve of an ecosystem (Monaco and Ulanowicz, 1997). The overheads provide limits on how much the ascendancy can increase and reflect the system's strength in reserve from which it can draw to meet unexpected perturbations (Ulanowicz, 1986). The relative values of ascendancy (31.2) and large overhead (68.8) in Lake Annecy show the ecosystem's stability and maturity. The large overhead of Lake Annecy belonged to phytoplankton, zooplankton and detritus. The overheads on imports and internal flows may be seen as a measurement of system stability sensu Odum. Lake Annecy concentrated its reserves on internal flow (55\%), which is normal for an oligotrophic lake.

MTI makes it possible to assess the effect that changes in the biomass of a group will have on the biomass of the other groups in a system. Prey has a positive impact on its predator, while a predator has negative impact on its prey. MTI, developed by Ulanowicz and Puccia (1990), can also be regarded as a form of "ordinary" sensitivity analysis. In Lake Annecy, the positive trophic impact of zoobenthos on almost all the fish species except whitefish was because zoobenthos formed a major portion of the diet of these species (Gerdeaux et al., 2002). All the functional groups except detritus have a negative impact on themselves, which shows competition for the same resources within the group (Christensen et al., 2005). Detritus has neither a positive nor negative impact on itself in Lake Annecy. This is in accordance with results from other lake ecosystems (Christensen and Pauly, 1993; Moreau et al., 2001; Fetahi and Mengistou, 2007; Panikkar and Khan, 2008). The positive impact of detritus can be seen on all the functional groups, showing the importance of detritus in Lake Annecy's ecosystem as observed in trophic flows. The same has been observed by Gamito and Erzini (2005) and Panikkar and Khan (2008). Pike has a negative impact on all the fish groups, being the top predator. The slight negative impact of whitefish on pike and Arctic char could be because of prey and predator niche overlap.

Both types of catches have a negative impact on target species and a small positive impact on groups at lower levels because of decrease in predation pressure and reduced competition when stock of predators and other major groups decline. Commercial fisheries show some small positive effect on Arctic char. Commercial fisheries are mostly composed of whitefish and decrease in whitefish density can have a positive effect on Arctic char, as explained earlier. According to Christensen et al. (2005), mixed trophic impact should be regarded as a tool for indicating the possible impact of direct and indirect interactions in a steady-state system and not as an instrument for making predictions of what will happen in the future if certain interaction terms are changed. Changes in abundance may lead to changes in diet composition and this cannot be accommodated by the mixed trophic impact analysis. The gross efficiency of the fishery, which is the correlation between primary production and fishery yields, is also important in trophic analysis. It can have a wide range in different systems, with high values in the systems with a fishery harvesting fish low in the food web, and can be low in systems whose fish stocks are underexploited. The value for Lake Annecy was 0.00117 , which is higher than the mean global value of 0.0002 reported by Christensen et al. (2005). However, it is quite comparable with 0.00114 in Lake Awassa (Fetahi and Mengistou, 2007) but less than Chinese lakes and many tropical African lakes (Villanueva et al., 2008). The average trophic level of the catch (TLc) is used as an index of sustainability 
and reflects the strategy of a fishery in terms of food web components selected. Mean trophic level is calculated as the weighted average of TL of the harvested species group (Christensen et al., 2005). The mean trophic level of fish catch in Lake Annecy was 3.17 because of a majority of salmonids in the fish catch. According to Pauly et al. (1998), fishery exploitation at higher trophic levels may result in immaturity. However, the percentage of Primary Production Required (PPR) to support fisheries in Lake Annecy was $14.98 \%$ of total primary production which is somewhat less than the global value of $23.6 \%$ for fresh water lakes (Pauly and Christensen, 1995). It shows that PP in Lake Annecy was quite enough to support more sustainable fishery exploitation. Tudela et al. (2005) proposed a framework for sustainable fisheries based on the pair of \%PPR and TLc. According to them, sustainably fished ecosystems involve a catch Trophic Level (TLC) of 3.0 and a low to moderate \%PPR (Tudela et al., 2005). In Lake Annecy TLc and \%PPR for fish catch are almost within this sustainable range.

\section{CONCLUSIONS}

The present analysis is an attempt to gather data on Lake Annecy and to construct a preliminary trophic model of Lake Annecy to evaluate trophic interactions with emphasis on fish groups. Parameter estimates of some functional groups might not be so accurate but despite this, the results obtained from this model are quite reasonable and the model is quite balanced. The Ecopath model appears to be a useful tool for understanding the trophic structure of Lake Annecy. From the present analysis it can be predicted that the producers and zooplankton are not fully exploited and primary production can support more fisheries. The present study is mostly focused on the properties of Lake Annecy's ecosystem and does not take into account the dynamics of the ecosystem. However, it will be interesting to establish a dynamic ecosystem model using the Ecosim approach to study the impact of change in fleet size (commercial and recreational fisheries) and as a result, change in biomass of fish groups, especially salmonids. Network analysis has shown the importance of a detritus-driven food chain. More studies are required on the productivity and biomass of zoobenthos, zooplankton, protozoa, bacteria and macrophytes and a microbial loop may be included in the model. More analysis of feeding habitats of some of the groups in Lake Annecy is also required. A preliminary model like this one can be useful in direct research as a benchmark by pinpointing information and data gaps in knowledge. As more information becomes available, it can be incorporated into the model to improve estimates and reduce uncertainty.

\section{ACKNOWLEDGEMENTS}

We are thankful to all the researchers, authors and fishermen of Lake Annecy for use of data and publications during the present study. The work was supported financially by INRA France and HEC, Pakistan through SFERE, France.

\section{REFERENCES}

Ainsworth C., Ferriss B., Leblond E. and Guénette S., 2001. The Bay of Biscay, France; 1998 and 1970 models. In: Guénette S., Christensen V. and Pauly D. (eds.), Fisheries impacts on North Atlantic ecosystems: models and analyses, The Fisheries Centre, University of British Columbia, Vancouver, Canada, 271-313.

Arbach Leloup F., Desroy N., Le Mao P., Pauly D. and Le Pape O., 2008. Interactions between a natural food web, shellfish farming and exotic species: The case of the Bay of Mont Saint-Michel (France). Estuar. Coast. Shelf Sci., 76, 111-120. 
Bailey M.M., 1972. Age, growth reproduction and food of burbot, Lota lota (Linnaeus) in southwestern Lake Superior. Trans. Am. Fish. Soc., 10, 667-674.

Balvay G., 1987. Équivalence entre quelques paramètres estimatifs de l'abondance du zooplancton total. Schweiz. Z. Hydrol., 49, 75-84.

Borderelle A.L., Verneaux V. and Gerdeaux D., 2005. Biological quality assessment of three French Alpine lakes (Lake Annecy, Lake Crop, Lake Grand Domenon) using the Lake Biotic Index (LBI). Arch. Hydrobiol., 162, 497-509.

Brando V.E., Ceccarelli R., Simone L. and Ravagnan G., 2004. Assessment of environmental management effects in a shallow water basin using mass balance models. Ecol. Model., 172, 213-232.

Christensen V., 1995. Ecosystem maturity-towards quantification. Ecol. Model., 77, 3-32.

Christensen V., 1998. Fishery induced changes in a marine ecosystem: insights from models of the Gulf of Thailand. J. Fish. Biol., 53, 128-142.

Christensen V. and Pauly D., 1992. ECOPATH II: a software for balancing steady state ecosystem models and calculating network characteristics. Ecol. Model., 61, 169-185.

Christensen V. and Pauly D., 1993. Trophic models of aquatic ecosystems. ICALRM Conference Proceedings, 26, Manila, Philippines.

Christensen V. and Pauly D., 1998. Changes in models of aquatic ecosystems approaching carrying capacity. Ecol. Appl., 8, 104-109.

Christensen V. and Walters C., 2004. Ecopath with Ecosim: methods, capabilities and limitations. Ecol. Model., 172, 109-139.

Christensen V., Walters C.J. and Pauly D., 2005. Ecopath with Ecosim: A user's guide, Fisheries Centre, University of British Columbia, Canada, $154 \mathrm{p}$.

Dame K.J. and Christian R.R., 2006. Uncertainty and the use of network analysis for ecosystem based fisheries management. Fisheries, 31, 331-341.

Dickie L.M., 1972. Food chains and fish production. ICNAF Spec. Publ., 8, 201-221.

Dubois J.P., Blake G., Gerbeaux P. and Brun G., 1988. Aquatic vegetation of lake Annecy. Schweiz. Z. Hydrol., 50, 95-110.

Fetahi T. and Mengistou S., 2007. Trophic analysis of Lake Awassa (Ethiopia) using mass-balance Ecopath model. Ecol. Model., 201, 398-408.

Froese R. and Binohlan C., 2000. Empirical relationships to estimate asymptotic length, length at first maturity, and length at maximum yield per recruit in fishes, with a simple method to evaluate length frequency data. J. Fish Biol., 56, 758-773.

Gamito S. and Erzini K., 2005. Trophic food web and ecosystem attributes of a water reservoir of the Ria Formosa (south Portugal). Ecol. Model., 181, 509-520.

Gerdeaux D. and Crepeau C., 2006. Suivi de la pêche au lac d'Annecy en 2006, INRA Rapport annuel pour les pêcheurs du lac Annecy, Thonon, France.

Gerdeaux D. and Janjua Y., 2009. Contribution of obligatory and voluntary fisheries statistics to the knowledge of whitefish population in Lake Annecy (France). Fish. Res., 96, 6-10.

Gerdeaux D., Angeli N., Balvay G., Druart J.C., Fontvieille D., Guillard J., Lafont M., Pelletier J., RosssoDarmet A., Verneaux J., Verneaux V. and Viboud S., 2000. Le fonctionnement trophique du lac d'Annecy, Rapport de fin de contrat, IXème Contrat Plan État-Région, Région Rhône, Alpes, France.

Gerdeaux D., Bergeret S., Fortin J. and Baronnet T., 2002. Diet and seasonal patterns of food composition of Coregonus lavaretus in Lake Annecy: comparison with the diet of the other species of the fish community. Arch. Hydrobiol., Spec. Issues Advanc. Limnol., 57, 199-207.

Gerdeaux D., Anneville O., Druart J.C., Lazzarototto J., Navarro L. and Robert M., 2005. Suivi de la qualité des eaux du Lac d'Annecy, Syndicat Mixte du lac d'Annecy, Annecy, France.

Halfon E. and Schito N., 1993. Lake Ontario food web, an energetic mass balance. In: Christensen V. and Pauly D. (eds.), Trophic models of aquatic ecosystems, ICALRM Conference Proceedings, 26, Manila, Philippines, 29-39.

Jamet J.L., 1994. Feeding activity of adult roach (Rutilus rutilus L.), perch (Perca fluviatilis L.) and ruffe (Gymnocephalus cernuus L.) in eutrophic Lake Aydat (France). Aquat. Sci., 56, 376-387.

Jorgensen S.E., 1979. Handbook of Environmental Data and Ecological Parameters, International Society of Ecological Modelling, Copenhagen, Denmark, $1162 \mathrm{p}$.

Kolding J., 1993. Trophic Interrelationships and Community Structure at Two Different Periods of Lake Turkana, Kenya: a Comparison Using the Ecopath II Box Model. In: Christensen V. and Pauly D. (eds.), Trophic models of aquatic ecosystems, ICALRM Conference Proceedings, 26, Manila, Philippines, 116-123. 
Lampert W., Sommer U. and Haney J.F., 1997. Limnocology: The Ecology of Lakes and Streams, Oxford University Press, New York, 400 p.

Le Roux M., 1911. Les poissons du lac d'Annecy et les essais de repeuplement. Revue Savoisienne, 41, 53-59

Li Y., Chen Y., Song B., Olson D., Yu N. and Chen L., 2009. Ecosystem structure and functioning of Lake Taihu (China) and the impacts of fishing. Fish. Res., 95, 309-324.

Lindeman R.L., 1942. The trophic dynamic aspect of ecology. Ecology, 23, 399-418.

Liu Q.G., Chen Y., Li J.L. and Chen L.Q., 2007. The food web structure and ecosystem properties of a filter-feeding carps dominated deep reservoir. Ecol. Model., 203, 279-289.

Mageau M.T., Constanza R. and Ulanowicz R.E., 1998. Quantifying the trends expected in developing ecosystems. Ecol. Model., 112, 1-22.

Michel P. and Oberdorff T., 1995. Feeding habits of fourteen European freshwater fish species. Cybium, 19, 5-46.

Monaco M.E. and Ulanowicz R.E., 1997. Comparative ecosystem trophic structure of three U.S. midAtlantic estuaries. Mar. Ecol. Prog. Ser., 161, 239-254.

Moreau J., 1995. Analysis of species changes in Lake Victoria using ECOPATH, a multispecies trophic model. In: Pitcher T.J. and Hart P.J.B. (eds.), The Impact of Species Changes in African Lakes, Chapman and Hall, London, 137-162.

Moreau J., Christensen V. and Pauly D., 1993. A trophic ecosystem model of Lake George, Uganda. In: Christensen V. and Pauly D. (eds.), Trophic models of aquatic ecosystems, ICALRM Conference Proceedings, 26, Manila, Philippines, 124-129.

Moreau J., Mavuti K. and Daufresne T., 2001. A synoptic Ecopath model of biomass flows during two different static ecological situations in Lake Nakuru (Kenya). Hydrobiologia, 458, 63-74.

Odum E.P., 1969. The Strategy of Ecosystem Development. Sciences, 164, 262-270.

Odum E.P., 1971. Fundamentals of Ecology, W.B. Saunders Co, Philadelphia, 574 p.

Palomares M.L.D. and Pauly D., 1998. Predicting food consumption of fish populations as functions of mortality, food type, morphometrics, temperature and salinity. Mar. Freshw. Res., 49, 447-453.

Palomares M.L., Horton K. and Moreau J., 1993a. An ECOPATH II Model of Lake Chad Ecosystem. In: Christensen V. and Pauly D. (eds.), Trophic models of aquatic ecosystems, ICALRM Conference Proceedings, 26, Manila, Philippines, 153-158.

Palomares M.L., Reyes-Marchant P., Lair N., Zainure M., Bernabe G. and Lasserre G., 1993b. A trophic model of Mediterranean Lagoon Étang de Thaw, France. In: Christensen V. and Pauly D. (eds.), Trophic models of aquatic ecosystems, ICALRM Conference Proceedings, 26, Manila, Philippines, 224-229.

Palomares M.L., Yuliants B., Puy L., Bengen D. and Belaud A., 1993c. A preliminary trophic model of Garonne River (Toulouse, France) ecosystem in spring. In: Christensen V. and Pauly D. (eds.), Trophic models of aquatic ecosystems, ICALRM Conference Proceedings, 26, Manila, Philippines, 172-179.

Panikkar P. and Khan M.F., 2008. Comparative mass-balanced trophic models to assess the impact of environmental management measures. Ecol. Model., 212, 280-291.

Pauly D. and Christensen V.,1995. Primary production required to sustain global fisheries. Nature, 374 , 255-257.

Pauly D., 1980. On the interrelationships between natural mortality, growth parameters, and mean environmental temperature in 175 fish stocks. ICES J. Mar. Sci., 39, 175-192.

Reyes-Marchant P., Jamet J.L., Lair N., Taleb H. and Palomares M.L.D., 1993. A preliminary ecosystem model of a eutrophic lake (Lake Aydat, France), In: Christensen V. and Pauly D. (eds.), Trophic models of aquatic ecosystems, ICALRM Conference Proceedings, 26, Manila, Philippines, 95-102.

Rybarczyk H. and Elkaïm B., 2003. An analysis of the trophic network of a macrotidal estuary: the Seine Estuary (Eastern Channel, Normandy, France). Estuar. Coast. Shelf Sci., 58, 775-791.

Stachowicz J.J., Fried H., Whitlatch R.B. and Osman R.W., 2002. Biodiversity, invasion resistance and marine ecosystem function: reconciling pattern and process. Ecology, 83, 2575- 2590.

Traore A., Ouattara A., Doumbia L., Tah L., Moreau J. and Gourène G., 2008. Trophic structure and interactions in Lake Ayamé (Côte d'Ivoire). Knowl. Managt. Aquatic Ecosyst., 388, 02.

Treasurer J.W., Owen R. and Bowers E., 1992. The population dynamics of pike, Esox lucius, and perch, Perca fluviatilis, in a simple predator-prey system. Environ. Biol. Fish., 34, 65-78.

Tudela S., Coll M. and Palomera I., 2005. Developing an operational reference framework for fisheries management on the basis of a two-dimensional index of ecosystem impact. ICES J. Mar. Sci., 62, 585-591. 
Ulanowicz R.E., 1986. Growth and Development: Ecosystems Phenomenology, Springer-Verlag, New York, USA, 203 p.

Ulanowicz R.E., 2000. Toward the measurement of ecological integrity. In: Pimentel D., Westra L. and Noss R.F. (eds.), Ecological Integrity, Island Press, Washington, USA, 102-113.

Ulanowicz R.E. and Puccia C.J., 1990. The mixed trophic impact routine. Coenose, 5, 7-16.

Verneaux V. and Verneaux J., 2002. Assessing lake functioning using the macrobenthic community with special reference to Chironomidae (Diptera). A subalpine lake (Lake Annecy) as an example. Arch. Hydrobiol., 154, 61-78.

Villanueva M.C., Ouedraogo M. and Moreau J., 2006. Trophic relationship in the recently impounded Bagré reservoir in Burkina Faso. Ecol. Model., 191, 243-259.

Villanueva M.C.S., Isumbisho M., Kaningini B., Moreau J. and Micha J.C., 2008. Modeling trophic interactions in Lake Kivu: What roles do exotics play? Ecol. Model., 212, 422-438.

Wolff M., 1994. A trophic model for Tongoy Bay - a system exposed to suspended scallop culture (Northern Chile). J. Exp. Mar. Biol. Ecol., 182, 149-168. 